J. Pijar MIPA, Vol. 15 No.1, Januari 2020: 88-92

DOI: $10.29303 /$ jpm.v15i1. 1406

ISSN 1907-1744 (Cetak)

ISSN 2460-1500 (Online)

\title{
PENGARUH PENGGUNAAN BAHAN AJAR IPA MATERI SISTEM EKSKRESI BERBASIS INKUIRI TERHADAP PENINGKATAN LITERASI SAINS
}

\section{THE EFFECT OF USING SCIENCE TEACHING MATERIALS BASED ON INQUIRY SYSTEM TO INCREASE EXCRETION OF SCIENCE LITERACY}

\author{
Fidiani Fidiantara*, Kusmiyati, I Wayan Merta \\ Program Studi Pendidikan Biologi, Jurusan Pendidikan MIPA, FKIP Universitas \\ Mataram Jalan Majapahit No. 62, Mataram \\ *Email: fidi.tara@gmail.com
}

Diterima : 15 Oktober 2019. Disetujui : 8 Januari 2020. Dipublikasikan: 31 Januari 2020

\begin{abstract}
Abstrak. Penelitian ini bertujuan untuk mengetahui peningkatan literasi sains pada materi Sistem Ekskresi siswa kelas VIII di MTsN 1 Mataram. Jenis penelitian adalah eksperimen semu (Quasi Experiment) dengan menggunakan bahan ajar berbasis inkuiri. Populasi penelitian adalah seluruh siswa kelas VIII MTs Negeri 1 Mataram pada tahun ajaran 2018/2019 yang berjumlah 8 kelas. Teknik pengambilan sampel dengan menggunakan teknik purposive sampling. Pengumpulan data dilakukan dengan menggunakan angket dan tes. Analisis data dilakukan dengan uji gain ternormalisasi dan uji hipotesis dengan menggunakan uji-t. Hasil penelitian menunjukkan tingkat literasi sains siswa pada kelas VIII'1 sebagai kelas eksperimen lebih tinggi dari pada kelas VIII'2 sebagai kelas kontrol yaitu pada kelas VIII'1 memiliki skor gain ternormalisasi sebesar 0,70 sedangkan kelas VIII'2 memiliki skor gain ternormalisasi sebesar 0,56, dan penigkatan literasi sains siswa masuk dalam kategori sedang. Hasil uji hipotesis dengan menggunakan uji-t menyatakan nilai thitung $(3,26)>t_{\text {tabel }}(1,67)$, yang berarti Ha diterima, sehingga penggunaan bahan ajar berbasis inkuiri dapat meningkatkan literasi sains siswa. Kesimpulan dari penelitian ini menunjukkan bahwa penggunaan bahan ajar berbasis inkuiri dapat meningkatkan literasi sains siswa kelas VIII MTs Negeri 1 Mataram.
\end{abstract}

Kata Kunci: Bahan Ajar, Inkuiri, Literasi Sains

\begin{abstract}
The purpose of this research was to identify scientific literacy level on excretion system learning materials of 8th grade students in MTsN 1 Mataram. The type of this research was Quasi-Experimental Method.by using learning materials with inquiry base. The population of this research was all of the 8th grade students in MTsN 1 Mataram Academic Year 2018/2019 with 8 classes. The sample collection technique used was purposive sampling. Collection data was executed by using inquiry and test. Data analysis was executed by using normalized gain and hypothetical experiment by using experiment 1 . The result of this research revealed that scientific literacy level of VIII1 as the experimental class was higher than VIII2 as controlled class that was on VIII1 class had normalized gain score with 0.70 , meanwhile VIII2 class had normalized gain score with 0.56 , and students' scientific literacy level was categorized as medium. The result of Hypothetical Experiment by using experiment 1 revealed that the value of $t_{\text {count }}(3.26)>t_{\text {table }}(1.67)$, that meant Ha was received, so the use of learning materials with inquiry base could increase students' scientific literacy level. The conclusion of this research revealed that the use of learning materials with inquiry base could increase 8th grade students' scientific literacy level in MTsN 1 Mataram.
\end{abstract}

Keywords: Learning Materials, Inquiry, Scientific Literacy

\section{PENDAHULUAN}

Pendidikan abad 21 memiliki peran penting dalam pembangunan dan kemajuan bangsa. Melalui pendidikan kita dapat meningkatkan kualitas sumber daya manusia (SDM), baik dari segi pengetahuan, keterampilan, dan sikap, serta memberikan bekal kompetensi kepada pelajar Indonesia sebagai generasi penerus yang menetukan perkembangan dan kemajuan bangsa. Terdapat beberapa tolak ukur yang dapat digunakan untuk melihat kemajuan suatu bangsa, salah satunya adalah dengan melihat kemajuan ilmu pengetahuan dan teknologi (IPTEK).

Pembelajaran IPA di suatu bangsa berperan penting dalam memajukan bangsa tersebut. IPA memiliki peran yang begitu krusial dalam proes pendidikan dan perkembangan teknologi, karena IPA memiliki cara untuk membangkitkan minat dan kemampuan manusia dalam mengembangkan ilmu 
pengetahuan dan teknologi. Jika dilihat pembelajaran IPA di negara-negara maju sudah berkembang sangat pesat, hal ini dapat dilihat dari penemuan-penemuan baru yang terkait dengan teknologi. Apabila dibandingkan dengan negara-negara maju, pembelajaran IPA di Indonesia masih tertinggal jauh. Pembelajaran IPA di Indonesia belum mencapai standar yang diinginkan, padahal IPA memiliki peranan penting untuk memajukan ilmu pengetahuan dan teknologi (IPTEK) dalam rangka memajukan bangsa [1].

Pelajaran IPA di sekolah memiliki tujuan untuk mempersiapkan peserta didik agar mampu (a) mempelajari sains pada jenjang pendidikan yang lebih tinggi; (b) memasuki tantangan dunia kerja dan menjalankan tugas dalam bidang kerjanya; serta (c) berkembang menjadi anggota masyarakat yang melek sains (science literate) atau memiliki literasi sains yang baik. Berdasarkan ketiga tujuan tersebut selain dituntut mempersiapkan diri untuk persaingan pendidikan dan dunia kerja pada abad 21 , peserta didik juga dituntut untuk memiliki kemampuan literasi sains (science literacy) yang baik. Secara sederhana literasi sains diartikan sebagai kemampuan menggunakan pengetahuan sains, mengidentifikasi pertanyaan, dan menarik kesimpulan berdasarkan bukti-bukti, dalam rangka memahami serta membuat keputusan terhadap suatu masalah [7].

Hasil survey tingkat literasi sains siswa menengah yang dilakukan Organisation for Economic Co-operation and Development (OECD) tahun 2015 menampilkan hasil bahwa tingkat literasi siswa di Indonesia masih pada tingkat yang rendah, walaupun poinnya meningkat dari survey yang dilakukan pada tahun 2012 Indonesia berada pada peringkat ke 61 dari 72 negara peserta. Rata-rata skor literasi sains siswa di Indonesia adalah sebesar 403 poin, padahal standar rata-rata skor dari OECD sebesar 501 poin. Hasil survey Programme for International Student Assessment (PISA) 2015 juga menunjukkan bahwa level literasi sains siswa di Indonesia berada pada level 1a, dan nyaris mencapai literasi sains level 2. Hal ini berarti bahwa siswa-siswa Indonesia memiliki kemampuan memilih penjelasan ilmiah yang paling baik untuk data yang diberikan dalam konteks pribadi yang familiar, lokal, dan global [9].

Kurnia, dkk [8] mengemukakan faktor-faktor rendahnya literasi sains siswa antara lain, kurikulum dan sistem pendidikan, pemilihan model dan metode pengajaran oleh guru, sarana, dan fasilitas belajar, sumber belajar, dan bahan ajar yang tidak memenuhi pembelajaran abad 21. Salah satu faktor yang harus diperhatikan untuk meningkatkan literasi sains siswa adalah bahan ajar yang sesuai kebutuhan siswa abad ke 21, yaitu bahan ajar yang di dalamnya memuat aspek literasi sain dan materi yang sesuai dengan tagihan kompetensi dan analisis kebutuhan siswa. Bahan ajar yang paling banyak digunakan oleh guru adalah bahan ajar dalam bentuk buku.

Salah satu aspek literasi sains menurut [7] adalah mampu menerapkan strategi inkuiri atau model yang sederhana untuk dapat menyelesaikan masalah. Dimana dalam proses pembelajarannya melibatkan siswa secara langsung dalam penyelidikan suatu masalah, membantu siswa mengidentifikasi konsep atau metode, dan mendorong siswa menemukan cara untuk memecahkan masalah yang dihadapi. Melalui pembelajaran inkuiri juga dapat mendorong siswa untuk berpikir dan bekerja atas inisiatifnya sendiri, bersikap objektif, jujur, dan terbuka. Sehingga dalam pembelajaran inkuiri dirasakan sangat cocok untuk dapat meningkatkan literasi sains dan membentuk karakter siswa di Indonesia.

Uraian tersebut menginspirasi penulis untuk melakukan penelitian yang dirumuskan dalam judul "Pengaruh Penggunaan Bahan Ajar IPA Materi Sistem Ekskresi Berbasis Inkuiri Terhadap Peningkatan Literasi Sains Siswa Kelas VIII MTs Negeri 1 Mataram".

Penelitian ini bertujuan untuk mengetahui "Apakah Pengunaan Bahan Ajar IPA Materi Sistem Ekskresi Berbasis Inkuiri Berpengaruh Terhadap Peningkatan Literasi Sains Siswa Kelas VIII MTs Negeri 1 Mataram".

\section{METODE PENELITIAN}

Jenis penelitian yang digunakan dalam penelitian ini adalah eksperimen semu (Quasi Experiment), dimana dalam penelitian ini variabel yang muncul dan kondisi eksperimen tidak bisa dikontrol secara penuh [10]. Penelitian dilaksanakan di MTs Negeri 1 Mataram dan Fakultas Keguruan dan Ilmu Pendidikan, Universitas Mataram. Penelitian ini dilaksanakan pada semester genap tahun ajaran 2018/2019 yakni pada tanggal 25 April sampai 31 Mei 2019. Variabel bebas pada penelitian ini adalah bahan ajar IPA materi sistem ekskresi berbasis inkuiri yang telah disusun oleh peneliti dan variabel terikatnya adalah literasi sains.

\section{Rancangan Penelitian}

Penelitian ini dilakukan di dua kelas, yakni kelas VIII'1 sebagai kelas eksperimen dan kelas VIII'2 sebagai kelas kontrol. Pembelajaran pada kelas kontrol menggunakan bahan ajar yang diterbitkan oleh Dinas Pendidikan, sedangkan untuk kelas eskperimen menggunakan bahan ajar yang disusun oleh peneliti.

\section{Prosedur Penelitian}

Ada tiga tahapan pada prosedur penelitian yakni tahap perencanaan, tahap pelaksanaa, tahap evaluasi. 


\section{Tahap Perencanaan}

Tahap perencanaan terdiri dari observasi data sekolah, analisis materi pelajaran biologi, analisis silabus dan penyusunan rencana pelaksanaan pembelajaran (RPP), bahan ajar, uji kelayakan bahan ajar, hasil uji kelayakan bahan ajar, intrumen tes, uji validitas dan realibilitas intrumen tes, hasil uji validitas dan realibilitas intrumen tes, hasil uji normalitas, uji homogenitas. Validasi bahan ajar dilakukan oleh 3 orang ahli yang terdiri dari 2 orang dosen ahli yakni Dr. Dadi Setiadi, M.Sc. sebagai ahli materi, Prof. Dr. H. A.Wahab Jufri M,Sc sebagai ahli media dan. seorang guru IPA di MTsN 1 Mataram yaitu Ibu Hj.Nur'Aini S.PdI. Insturmen tes telah diuji cobakan pada kelas di luar sampel, sehingga diperoleh instrumen soal yang valid dan reliabel berjumlah 30 soal pilihan ganda.

\section{Tahap Pelaksanaan}

Penelitian dilaksanakan pada semester genap tahun ajaran 2018/2019 di MTs Negeri 1 Mataram dengan sampel sebanyak 2 kelas. Penelitian ini dilaksanakan selama 7 kali pertemuan. Pada pertemuan pertama dilakukan pre-test pada siswa kelas eksperimen dan kelas kontrol untuk mengetahui kemampuan awal siswa sebelum perlakuan. Kemudian, pada pertemuan kedua sampai keenam dilaksanakan kegiatan pembelajaran dengan menggunakan bahan ajar berbasis inkuiri pada kelas eksperimen dan menggunakan bahan ajar yang diterbitkan oleh Dapertemen Pendidikan Nasional pada kelas kontrol. Di akhir pertemuan ketujuh pada kelas eksperimen dan kelas kontrol diberikan post-test untuk mengetahui pengaruh perlakuan yang telah diberikan.

\section{Tahap Evaluasi}

Tahap evaluasi merupakan tahapan yang dilaksanakan pada akhir proses pembelajaran. Tahap evaluasi diberikan pada kelas eksperimen dan kelas kontrol setelah diberikan perlakuan yang berbeda. Evaluasi yang diberikan tersebut bertujuan untuk mengetahui peningkatan literasi sains siswa setelah diberikan perlakuan yang berbeda. Pengumpulan data hasil belajar untuk ranah kognitif diperoleh dari tes literasi sains siswa dengan melakukan post-test. Hasil tes literasi sains siswa berupa post-test yang diperoleh akan diuji yaitu berupa uji hipotesis.

\section{Teknik Pengumpulan Data}

Teknik pengumpulan data dalam penelitian ini menggunakan angket dan tes. Angket digunakan peneliti untuk memperoleh informasi secara obyektif berdasarkan daftar pernyataan beserta alternatif jawaban yang dapat dipilih oleh responden. Tes tulis digunakan untuk mengetahui tingkat pengetahuan dan penguasaan siswa terhadap materi IPA yaitu Sistem Ekskresi Manusia. Tes tulis yang digunakan oleh peneliti yaitu berupa soal pilihan ganda terdiri dari 30 butir soal dengan masing-masing 5 alternatif jawaban yang terdiri dari 1 jawaban benar dan 4 jawaban salah.

\section{Analisis Data}

Analisis data peningkatan literasi sains menggunakan rumus gain ternormalisasi $(\mathrm{g})$, rumus yang dikemukakan oleh [3] sebagai berikut:

$$
\text { Gain Ternormalisasi }(g)=\frac{\text { Spost }- \text { Spre }}{\text { Smaks }- \text { Spre }}
$$

Keterangan :

Spost $=$ skor pos tes

Spre $=$ skor pre tes

Smaks $=$ skor maksimal

Uji hipotesis yang digunakan adalah Uji-t yakni Independent Sample T-Test, alasan peneliti menggunakan uji ini karena data yang diperoleh normal dan homogen pada kelas kontrol dan eksperimen. Adapun rumus Uji-t yang digunakan yaitu sebagai berikut [2]:

$$
\mathrm{t}_{\text {hitung }}=\frac{[\mathrm{Mx}-\mathrm{My}]}{\sqrt{\frac{\sum x^{2}+\sum y^{2}}{\mathrm{Nx}+\mathrm{Ny}-2}\left(\frac{1}{\mathrm{Nx}}+\frac{1}{\mathrm{Ny}}\right)}}
$$

Keterangan:

$\mathrm{MX}=$ nilai rata-rata kelas eksperimen

$\mathrm{MY}=$ nilai rata-rata kelas kontrol

$\mathrm{N}$ = banyaknya subyek

$\mathrm{x}=$ deviasi nilai pre-test $\mathrm{dan}$ post-test kelas eksperimen

$\mathrm{y}=$ deviasi nilai pre-test dan post-test kelas kontrol

Analisis data respon siswa terhadap bahan ajar dengan cara menjumlahkan jawaban yang dipilih siswa dibagi skor total per soal dikali seratus. Hasil analisi data akan dikualitatifkan dalam yaitu kurang menarik, cukup menarik, menarik, dan sangat menarik. Data respon siswa didapatkan dari hasil angket yang terdiri dari 13 butir soal dengan tiga aspek penilaian. Data siswa menjadi data tambahan dari sudut pandang pengguna bahan ajar yang digunakan.

\section{HASIL DAN PEMBAHASAN Data Uji Gain Ternormalisasi}

Analisis data gain ternormalisasi di kelas kontrol didapatkan hasil sebesar 0,56 dan di kelas eksperimen sebesar 0,70. Kelas eksperimen dan kontrol sama-sama mengalami peningkatan sedang, namun pada kelas eksperimen peningkatannya lebih tinggi di bandingkan di kelas kontrol. Perbedaan tingkat literasi sains kelas VIII'1 DAN VIII'2 digambarkan pada Gambar 1.1 berikut: 


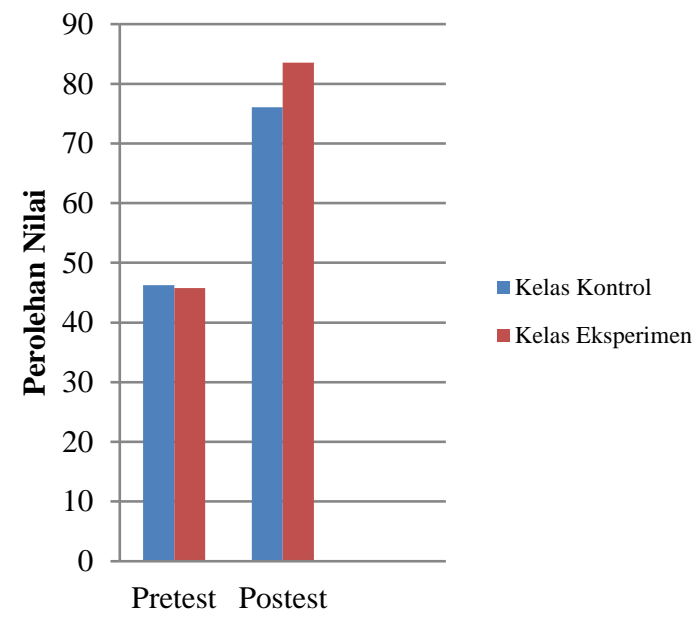

Gambar 1.1 Deskripsi perbedaan tingkat literasi sains peserta didik di kelas kontrol dan eksperimen

\section{Data Hasil Uji Hipotesis (Uji-t)}

Uji hipotesis yang digunakan adalah Uji-t karena data yang diperoleh adalah normal dan homogen. Uji-t digunakan pada penelitian yang terdapat kelompok kontrol dan kelompok eksperimen yang keduanya diberikan pre-test dan post-test, pengujian yang dilakukan bukan terhadap nilai ratarata tetapi terhadap selisih atau perbedaan nilai ratarata [2].

Berdasarkan data hasil uji hipotesis didapatkan hasil $t_{\text {hitung }}$ sebesar 3,26 $>t_{\text {tabel }}$ sebesar 1,670 yang berarti Ho ditolak dan Ha diterima, maka penggunaan bahan ajar IPA materi Sistem Ekskresi berbasis inkuiri dapat meningkatkan literasi sains siswa kelas VIII di MTs Negeri 1 Mataram.

\section{Data Angket Respon Siswa}

Data respon siswa terhadap bahan ajar berbasis inkuiri yang disusun oleh peneliti menunjukkan bahwa bahan ajar berbasis inkuiri secara kualitatif masuk dalam kategori menarik. Data hasil angket respon siswa terangkum dalam Tabel 1.1 berikut:

\begin{tabular}{lcccc}
\hline \multirow{1}{*}{ Aspek } & \multicolumn{4}{c}{ Persentase Siswa (\%) } \\
& Kurang & Cukup & Menarik & $\begin{array}{c}\text { Sangat } \\
\text { Menarik }\end{array}$ \\
\hline Penyajian & 0 & 19,35 & 60,22 & 20,43 \\
Bahasa & 0 & 17,74 & 53,23 & 29,03 \\
Isi & 0 & 19,89 & 48,39 & 31,72 \\
\hline Total (\%) & 0 & 18,99 & 53,95 & 27,06 \\
\hline
\end{tabular}

Tabel 1.1 menunjukkan bahwa 3 aspek penilaian yang terdiri dari 13 butir pernyataan dalam kategori cukup, menarik, dan sangat menarik. Secara keselurahan bahan ajar berbasis inkuiri dari sudut pandang pengguna dinyatakan menarik digunakan dengan persentase sebesar $53,95 \%$, sedangkan untuk kategori sangat menarik, cukup, dan kurang mendapatkan persentase berturut-turut sebesar 27,06\%, $18,99 \%$, dan $0 \%$.

\section{PEMBAHASAN}

Penelitian yang telah dilaksanakan dengan menggunakan bahan ajar berbasis inkuiri pada materi sistem ekskresi pada siswa kelas VIII MTsN 1 Mataram, menunjukkan bahwa literasi sains peserta didik meningkat. Peningkatan literasi sains peserta didik terlihat dari rata-rata pre-test atau nilai rata-rata peserta didik sebelum kegiatan pembelajaran dengan menggunakan bahan ajar berbasis inkuiri adalah sebesar 46,00 yang meningkat menjadi 83,55 pada posttest atau nilai rata-rata sesudah kegiatan pembelajaran dengan menggunakan bahan ajar berbasis inkuiri.

Hasil penelitian tersebut menunjukkan bahwa bahan ajar berbasis inkuiri terbukti dapat meningkatkan hasil belajar IPA siswa kelas VIII MTsN 1 Mataram pada materi sistem ekskresi, dan dengan pembelajaran inkuiri siswa lebih aktif mengikuti pembelajaran, keinginan belajar siswa meningkat dan dapat mempengaruhi literasi sains siswa. Hasil analisis gain ternormalisasi didapatkan bahwa literasi sains siswa kelas eksperimen (VIII'1) memiliki nilai rata-rata yang meningkat dari pre-test sebesar 46,00 dan nilai rata-rata post-test sebesar 83,55 dengan peningkatan 0,7 yang termasuk ke dalam kategori sedang. Literasi siswa kelas kontrol (VIII'2) mimiliki nilai rata-rata pre-test sebesar 46,03 dan nilai rata-rata post-test sebesar 76,26 yang mengalami peningkatan sebesar 0,56 yang berarti ketegori sedang. Meskipun sama-sama memiliki peningkatan sedang, kelas eksperimen memiliki tingkat peningkatan yang lebih tinggi dibandingkan kelas kontrol. Hasil dari uji hipotesis juga menyatakan bahwa bahan ajar berbasis inkuiri dapat untuk meningkatkan litarasi sains siswa, yakni nilai $t_{\text {hitung }}$ sebesar 3,26, sedangkan $\mathrm{t}_{\text {tabel }}$ sebesar 1,67, yang berarti $\mathrm{H}_{0}$ ditolak.

Hasil penelitian ini sesuai dengan hasil penelitian sebelumnya yang telah dilakukan oleh [4] tentang pengembangan bahan ajar berbasis inkuiri dalam meningkatkan literasi sains pada materi gerak makhluk hidup kelas VIII MTsN 2 Mataram. Proses pembelajaran dengan menggunakan bahan ajar berbasis inkuiri berhasil meningkatkan literasi sains siswa, dimana nilai gain ternormalisasi pada uji lapangan 1 sebesar 0,37 dan uji lapangan 2 sebesar 0,43 yang termasuk dalam ketegori peningkatan sedang.

Hasil penelitian lain yang juga mendukung penelitian ini adalah peneltian yang telah dilakukan oleh [5], dimana bahan ajar yang dikembangkan berbentuk modul berbasis inkuiri yang dikembangkan untuk meningkatkan hasil belajar siswa. Pengembangan 
bahan ajar berbasis inkuiri yang dilakukan oleh [5] tersebut menyatakan bahwa hasil belajar siswa dapat meningkat dengan menggunakan modul berbasis inkuiri. Modul berbasis inkuiri yang dikembangkannya berisi modul yang dapat mengkondisikan kegiatan pembelajaran IPA yang lebih terencana dengan baik, mandiri, tuntas, dan dengan hasil yang jelas.

Bahan ajar berbasis inkuiri pada materi sistem ekskresi merupakan bahan ajar yang di dalamnya terdapat kegiatan inkuiri yang dapat dilkakukan peserta dengan mudah. Karakteristik pada bahan ajar berbasis inkuiri yang dikembangkan meliputi uraian materi singkat dan pertanyaan-pertanyaan selingan yang memancing siswa untuk mencari tahu jawaban sendiri, panduan aktivitas inkuiri peserta didik, mari berpikir kritis, dan daftar kata penting. Mengutip [9] bahwa aktivitas inkuiri merupakan salah satu tujuan utama literasi sains pada individu atau kelompok.

Keterkaitan bahan ajar berbasis inkuiri dengan kenaikan tingkat literasi sains saling terhubung satu sama lain. Hal ini berdasarkan fakta bahwa kegiatan inkuiri dianggap dapat meningkatkan tingkat litarsi sains karena mampu melatih siswa untuk melakukan sains itu sendiri, baik dalam pembelajaran menggunakan bahan ajar berbasis inkuiri di dalam kelas, maupun penerapan sains pada kehidupan sehari-hari. Kurangnya kegiatan siswa untuk meningkatkan literasi sain dan inkuiri pada kegiatan pembelajaran IPA dikhawatirkan akan membuat kualitas pembelajaran menjadi menurun. Hal ini sesuai dengan yang dikemukakan oleh [6] yaitu, masalah kemelekan sain (science literacy) dan kemelekan inkuiri (inquiry literacy) akan berdampak pada perkembangan keterampiln berpikir siswa sebagai bagian dari komponen-komponen kecakapan hidup.

Bahan ajar berbasis inkuiri menjadi perlu dikembangkan dengan tujuan aktivitas inkuiri dalam bahan ajar yang digunakan siswa untuk mengarahkan, mendorong peserta didik berusaha melakukan kegiatan yang dapat meningkatkan tingkat literasi sainnya. Keuntungan peserta didik yang dapat meningkatkan literasi sainsnya menurut [11] adalah peserta didik akan memiliki kemampuan akademik dan karir profesional yang efektif sejalan dengan meningkatnya tingkat litarasi sainsnya, hal ini terjadi sebagai timbal balik karena usaha peserta didik untuk meningkatkan tingkat literasi sainsnya.

\section{KESIMPULAN}

Berdasarkan hasil analisis data dan pembahasan maka dapat disimpulkan bahwa bahan ajar berbasis inkuiri berpengaruh untuk meningkatkan literasi sains siswa. Pernyataan ini didukung dengan hasil analisis gain ternormalisasi yakni pada sebesar
0,70 yang termasuk dalam kategori sedang dan uji hipotesis menggunakan uji-t yang mendapatkan $t_{\text {hitung }}$ sebesar 3,26, sedangkan $t_{\text {tabel }}$ sebesar 1,67, yang berarti $\mathrm{H}_{0}$ ditolak.

\section{DAFTAR PUSTAKA}

[1] Arikunto, S. (2010). Prosedur Penelitian: Suatu Pendekatan Praktik. Jakarta: Rineka Cipta.

[2] Hake, R.R. (1999). Analyzing Change/Gain Scores. Diaksesdari Indiana Education: http://www.physics.indiana.edu/sdi/AnalyzingCh ange-Gain.pdf, pada tanggal 11 Desember 2018.

[3] Hijrati, I. (2018). Pengembangan Bahan Ajar Berbasis Inkuiri Dalam Meningkatkan Literasi Sains Siswa Kelas Viii Pada Materi Gerak Makhluk Hidup Di MTsN 2 Mataram [Skripsi]. Mataram: Universitas Mataram.

[4] Ikhsan, M., Sutarno, \& Prayitno, B. A. (2016). Pengembangan Modul Berbasis Inkuiri Terbimbing pada Sistem Gerak Manusia untuk Meningkatkan Hasil Belajar Siswa Kelas XI MIA SMA Negeri 1 Wera Kabupaten Wera Nusa Tenggara Barat . Jurnal Inkuiri, 5 (1), 133-142.

[5] Jufri, A. W., dan Hikmawati. (2014). Analisis Kemelekan Sains (Science Literacy) dan Kemelekan Inkuiri (Inquiry Literacy) Guru Mata Pelajaran IPA SMP. Jurnal Pijar MIPA, 9 (1), 914.

[6] Jufri, A.W. (2017). Belajar dan Pembelajaran Sains Modal Dasar Menjadi Guru Profesional. Bandung: Pustaka Rineka Cipta.

[7] Priscylio, G., \& Anwar, S. (2019). Integrasi Bahan Ajar IPA Menggunakan Model Robin Fogarty Untuk Proses Pembelajaran IPA di SMP. Jurnal Pijar Mipa, 14(1), 1-12.

[8] Kurnia, F., Zulherman, \& Fathurohman, A. (2014). Analisis Bahan Ajar Fisika SMA Kelas XI di Kecamatan Indralaya Utara berdasarkan Kategori Literasi Sains. Jurnal Inovasi dan Pembelajaran Fisika, 1 (1), 43-47.

[9] OECD. (2016). PISA 2015 Results (Volume I): Excellence and Equity in Education. Paris: OECD Publishing.

[10] Sugiyono. (2017). Metode Penelitian. Bandung: Alfabeta.

[11] Sulun, Y., Yurttas, G. D., \& Ekiz, S. O. (2009). Determination of Science Literacy Level of The Classroom Teachers (A Case of Mugla City in Turkey). Procedia Social and Behavioral Science I, 1 (1), 723-730. 